
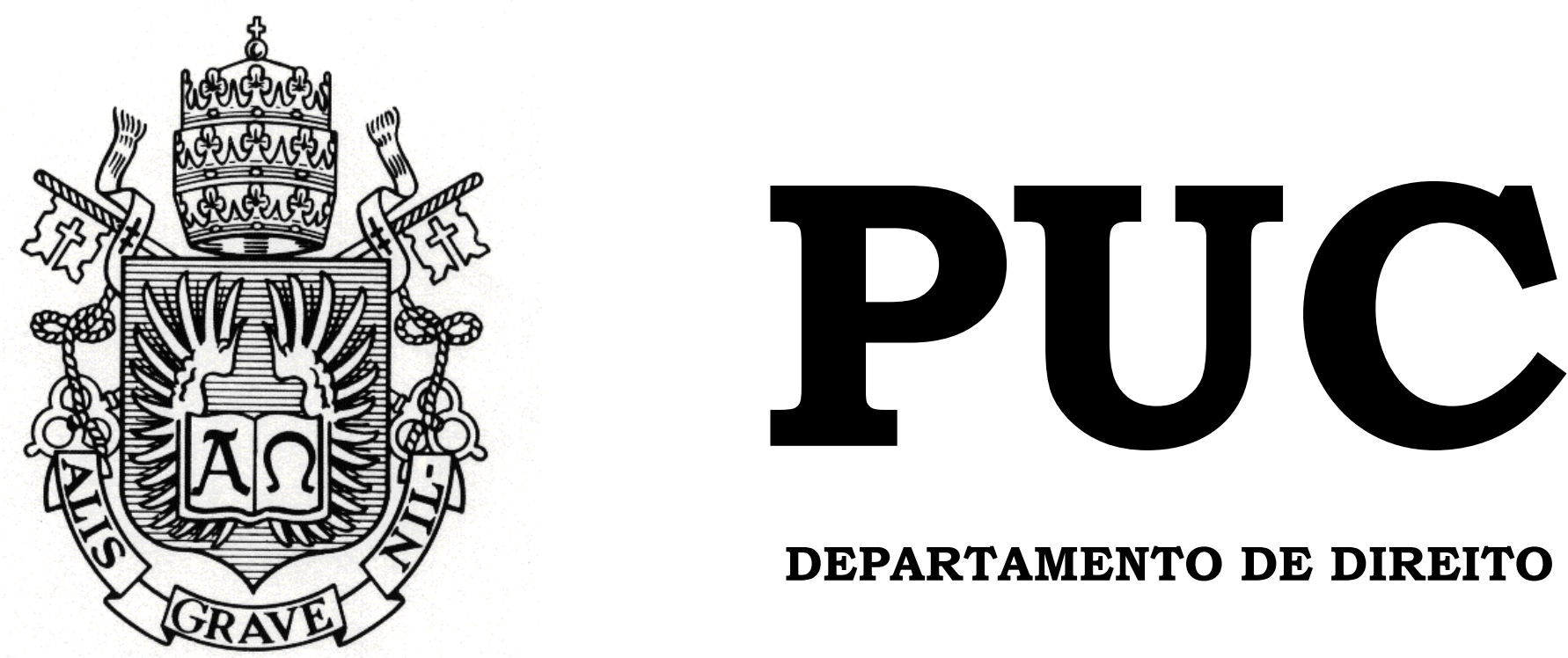

DEPARTAMENTO DE DIREITO

O CRIME DE INSIDER TRADING

por

JULIEN DE CARVALHO RICHARD

ORIENTADOR: Sérgio Chastinet Duarte Guimarães 2017.1

PONTIFÍCIA UNIVERSIDADE CATÓLICA DO RIO DE JANEIRO RUA MARQUÊS DE SÃO VICENTE, 225 - CEP 22453-900 RIO DE JANEIRO - BRASIL 


\section{O CRIME DE INSIDER TRADING}

por

\section{JULIEN DE CARVALHO RICHARD}

Monografia apresentada ao Departamento de Direito da Pontificia Universidade Católica do Rio de Janeiro (PUC-Rio) como requisito parcial para obtenção do título de Bacharel em Direito.

Orientador: Sérgio Chastinet Duarte Guimarães 
Dedico este trabalho à minha mãe, a quem devo tudo que tenho e sou. 


\section{AGRADECIMENTOS}

Agradeço à minha mãe, por sempre me apoiar, me ensinar, e me amar.

Ao meu irmão e à minha irmã, pela paciência e apoio.

À Lia, por tudo.

Ao Professor Sérgio, pela orientação e pelos valiosos ensinamentos.

Ao Augusto, sem quem esta monografia não seria possível.

Ao meu pai (in memoriam). Espero que esteja em paz. 


\section{RESUMO}

O presente trabalho tem por objetivo fazer uma análise do crime de insider trading (uso indevido de informação privilegiada), aproveitando o pano de fundo teórico já desenvolvido pela doutrina. É feita uma breve contextualização do delito, indispensável para uma análise robusta. Também são abordados certos conceitos inerentes ao ambiente no qual a conduta do insider trading costuma ser praticada, como a noção de fato relevante.

O foco da presente monografia foi abordar criticamente os elementos que constituem o crime em questão, traçando o quadro necessário para compreender seu propósito e sua aplicação no ordenamento jurídico brasileiro.

Palavras-chave: Direito Penal Econômico. Insider Trading. Uso Indevido de Informação Privilegiada. Mercado de Capitais. 


\section{LISTA DE ABREVIATURAS}

SEC Securities and Exchange Commission

TGS Texas Gulf Sulphur

CVM Comissão de Valores Mobiliários 


\section{SUMÁRIO}

INTRODUÇÃO.

.08

CAPÍTULO 1 - A CONTEXTUALIZAÇÃO DO CRIME DE INSIDER

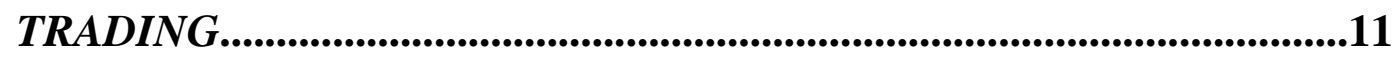

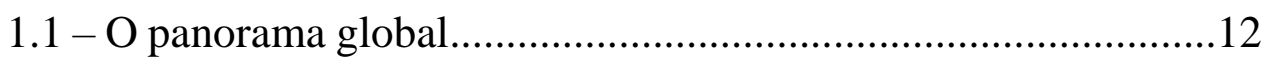

1.2 - A expansão do direito penal.....................................................13

CAPÍTULO 2 - ANÁLISE DO CRIME DE INSIDER TRADING..........16

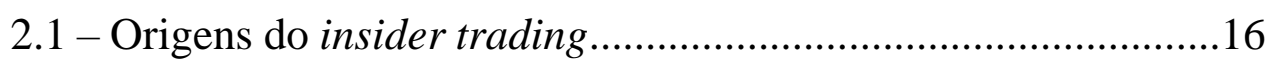

2.2 - Bem jurídico tutelado pelo crime de uso indevido de informação privilegiada 19

2.3 - Análise do tipo penal..............................................................22

2.3.1 - Objeto do crime............................................................22

2.3.2 - Tipo subjetivo - dolo e culpa........................................24

2.4 - Agente e vítima no insider trading..............................................29

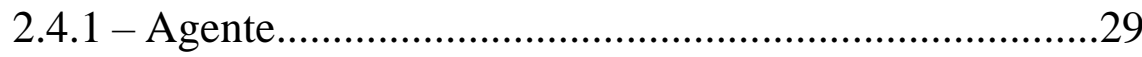

2.4.1.1 - Insider primário................................................. 30

2.4.1.2 - Insider secundário............................................30

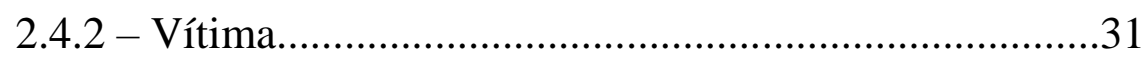

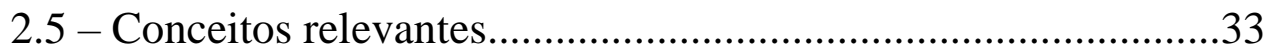

2.5.1 - Fato relevante..............................................................33

2.5.2 - Dever de diligência......................................................... 37

2.5.3 - Dever de lealdade .............................................................39

2.5.4 - Práticas não-equitativas.................................................41

2.6 - Considerações gerais sobre o crime de insider trading...............43

2.6.1 - Consumação do crime de uso indevido de informação privilegiada. 
CAPÍtULO 3 - MATÉRIAS ACESSÓRIAS E CONSIDERAÇÕES FINAIS SOBRE O INSIDER TRADING ..........................................47

3.1 - Análise da prevenção geral e especial no crime de uso indevido

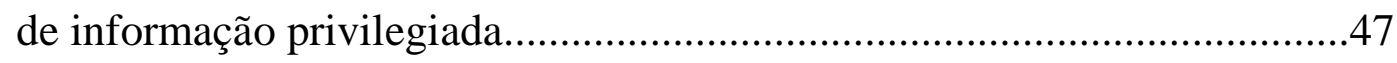

3.2 - Tutela penal ou administrativa?................................................49

3.3 - The Market for lemons e o insider trading...................................53

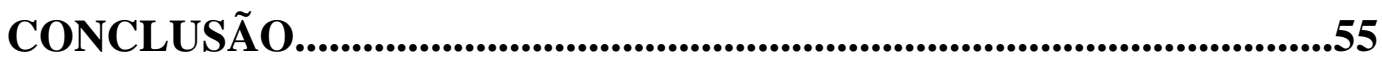

BIBLIOGRAFIA.......................................................................57 


\section{INTRODUÇÃO}

Os crimes contra o mercado de capitais surgiram envoltos em controvérsias doutrinárias, e assim permanecem. $\mathrm{O}$ crime de insider trading foi inserido na nossa legislação em 2001, e desde então vem sendo discutido e gerando teses que se entrelaçam com todas as questões próprias do direito penal econômico.

Apesar de ser um crime relativamente recente no nosso ordenamento jurídico, o insider trading foi alvo de interessantes estudos, tanto nas searas societária e administrativa quanto na seara penal. Acreditamos que o desenvolvimento contínuo da questão é necessário para que haja uma pacificação rápida sobre o assunto. Entendemos que o conflito de opiniões e correntes sobre o assunto (que são diversas) devem ser enfrentados imediatamente. A produção acadêmica sobre insider trading não deve necessariamente buscar um entendimento unificado, mas trazer à tona as

questões controvertidas para que sejam resolvidas de pronto. Não há consenso perfeito, e é colocando as cartas na mesa que se poderão escolher as mais aceitáveis.

Escolhemos o crime de insider trading em razão de sua crescente relevância. A primeira condenação criminal pela conduta ocorreu em 2016, e foi confirmada em 2017. Em maio de 2017, a JBS foi investigada pela Comissão de Valores Mobiliárias por prática de insider trading ao comprar dólar utilizando informação privilegiada sobre a delação de Joesley Batista (e outros). Claramente, o crime vem ganhando destaque no nosso ordenamento jurídico, e a escassez da jurisprudência sobre o assunto o torna interessante de ser desenvolvido na doutrina. 
A premissa do presente trabalho é construir um entendimento próprio com base no corpo doutrinário desenvolvido sobre a questão, e não servir necessariamente de referência. Trata-se apenas de uma exploração curiosa.

Não procuramos repetir as opiniões já reiteradamente reproduzidas em outros trabalhos acadêmicos, buscando apenas reintroduzir aquelas absolutamente necessárias para prosseguir com o trabalho. Certas contextualizações e apoios doutrinários são necessários, mas visamos cortar o máximo de recapitulações possíveis. Outros juristas já fizeram compilações sublimes sobre as diferentes correntes que existem na discussão referente ao insider trading. As aqui reproduzidas servem de apoio para os entendimentos que desenvolvemos.

Para ter um panorama robusto do tema, iniciamos o primeiro capítulo com uma breve contextualização do crime de insider trading. Discutimos rapidamente a evolução do direito penal econômico e a financeirização, ambos elementos dignos de nota.

Em seguida, no segundo capítulo, adentramos a discussão principal deste trabalho: a análise do crime de insider trading. Faremos uma breve análise das origens do insider trading para ambientar a discussão e, logo após, trataremos a controvertida discussão acerca do bem jurídico tutelado pelo tipo penal. Com esta base edificada, entraremos na análise propriamente dita, passando um olhar crítico sobre o objeto do crime, o tipo subjetivo, e fazendo considerações importantes sobre o agente e a vítima no crime de insider trading.

Ainda no segundo capítulo, separamos um item no intuito de elucidar rapidamente certos conceitos societários essenciais à compreensão do insider trading. Apesar de não fazer parte da discussão acerca do crime em si, 
consideramos que se trata de informação indispensável para o trabalho que nos propomos a fazer.

Concluímos o segundo capítulo com algumas considerações importantes acerca do delito, notadamente as controvérsias acerca da sua consumação e a análise da pena e de sua adequação para a efetiva repressão à conduta.

No terceiro e último capítulo, traremos três tópicos acessórios que consideramos interessantes. Em primeiro lugar, a discussão acerca da prevenção geral e especial no crime de insider trading, o que nos leva diretamente à discussão acerca da necessidade ou não da tutela penal para a repressão à conduta. Por fim, trazemos a teoria do The Market for Lemons, traçando um paralelo com os impactos do insider trading para o Mercado de Capitais. Em seguida, apresentamos nossas conclusões. 


\section{CAPÍTULO 1 - A contextualização do crime de insider trading}

O crime de uso indevido de informação privilegiada é uma das manifestações do desconforto que o nosso direito penal sente com os avanços da sociedade. Para entender a formulação do conceito de insider trading, devemos primeiramente entender o contexto que forçou seu surgimento.

A evolução da nossa sociedade se deu, em tempos recentes, graças ao avanço da tecnologia e à consequente globalização que explodiu com ela. $\mathrm{O}$ advento da internet deu ensejo ao esfacelamento das fronteiras do mundo, criando um novo cenário global. A economia não escapou desse movimento, e o mercado de capitais de forma geral se tornou um ator essencial nesta nova dinâmica.

Tendo em mente este panorama, entendemos melhor o surgimento do fenômeno da financeirização. Ignorando fronteiras, as operações no mercado de capitais e toda a estrutura econômica virtual que se expandiu rapidamente acabaram por favorecer uma estrutura financeirizada como jamais vista antes. Tal financeirização trouxe novas situações e novos riscos, ambos com os quais o direito não soube lidar inicialmente, e com os quais ainda tem dificuldade.

Repentinamente, se buscava tutelar bens afetados pela financeirização, sem se saber ao certo quais eram. De uma coisa o direito tinha certeza: sem tutela e regulação, haveria consequências.

Com o aumento do protagonismo do mercado de capitais, certas práticas passaram a ser discutidas com maior atenção. $\mathrm{O}$ uso indevido de informação privilegiada ganhou mais foco, posto que o uso da informação passou a ter impacto cada vez maior. 
Num mundo onde qualquer cidadão com acesso à internet pode investir e participar ativamente no mercado de capitais, o uso de informação privilegiada passa a ser um assunto de suma importância.

Tendo em mente que o crime de uso indevido de informação privilegiada está inserido num contexto extremamente específico, recente, e controvertido, não seria possível discuti-lo sem antes passarmos brevemente pelo cenário ao qual pertence.

\section{1 - O panorama global}

O domínio econômico sempre foi uma das questões mais importantes para os impérios e as nações do mundo. A regulação e a tutela da economia não têm impacto apenas no local, mas no próprio desenvolvimento econômico em si. As práticas permitidas ou proibidas acabam por moldar o paradigma vigente, posto que direcionam instituições essenciais (como o mercado de capitais).

Percebemos que os avanços tecnológicos são indicadores convincentes disso. A cada passo dado, o mercado segue na mesma direção. A cada inovação tecnológica, surge uma maneira de a economia se adaptar. A cada inovação, surge uma necessidade de formular e aplicar um direito novo ou, no mínimo, atualizado.

O próprio termo 'nação' vem perdendo significado neste contexto. A globalização vem desafiando a ideia de que ordenamentos jurídicos e sistemas econômicos são independentes e isolados, deixando clara a ligação que se fortifica a cada avanço tecnológico.

A crise de 2008 é prova do 'ripple effect' que desastres econômicos supostamente locais e nacionais têm sobre o resto do mundo. A internet se 
mostrou como divisor de águas em termos de globalização da economia. Percebe-se que, em termos econômicos, as fronteiras perdem cada vez mais relevância.

Dito isso, é importante lembrarmos que a globalização não implica necessariamente na eliminação da ideia de soberania, muito pelo contrário.

Não tendo mais as rédeas da economia, os Estados se viram na necessidade de exercer controle sobre os mercados em si. A soberania sobrevive através de legislações domésticas, e se impõe ao mercado que ganha dimensão cada vez mais internacional.

Enquanto a expansão e consequente internacionalização dos mercados de capitais trouxeram uma menor intervenção estatal no âmbito das operações de mercado, fica claro que a reação do estado ocorreu na seara do direito penal.

Tendo que flexibilizar sua atuação no mercado por conta do dinamismo inerente ao mesmo, o Estado se sentiu na necessidade de utilizar o direito penal para criar novos ilícitos referentes ao mercado de capitais (como o crime de insider trading). Em parte para exercer sua soberania, em parte para tentar se adaptar ao novo paradigma. É a partir deste cenário global que se expande o direito penal econômico.

\section{2 - A expansão do direito penal}

Posto de frente com este cenário, o mundo se viu obrigado a expandir o direito penal. Enquanto o mercado de capitais e outras instituições semelhantes se internacionalizaram, o direito se concentrou na esfera nacional. 
Como vimos, as circunstâncias mudaram tremendamente, e o direito vem tendo dificuldades em se adaptar. Um primeiro reflexo desta dificuldade foi a inaptidão do direito penal clássico para lidar com as condutas dignas de tutela penal referentes ao mercado de capitais.

Como resposta a essa inaptidão, nos deparamos com a denominada 'expansão do direito penal'. Trazendo consigo uma forte flexibilização das garantias e bases do direito penal clássico, essa expansão visou dar conta do direito penal econômico emergente.

Ante o exposto, percebemos que o cenário atual é confuso, e fica evidente o desconforto que mencionamos anteriormente. A própria existência da figura do crime de perigo abstrato, amplamente utilizada para justificar o tratamento dado aos crimes contra o mercado de capitais, é prova disso.

Seguindo adiante, entendemos que um dos fatores mais relevantes no que tange a expansão do direito penal é a sua motivação inicial. Diversos autores entendem que o surgimento do direito penal econômico se deu, em grande parte, como uma maneira de apaziguar um clamor da sociedade, sendo uma ferramenta simbólica.

Através desta perspectiva entendemos como a expansão do direito penal acabou por enveredar pela minoração de garantias: quando se trata de acalmar a multidão, a solução que mais convém é aquela que mais rapidamente lida com a questão.

Com isso, temos um direito penal extremamente perigoso e propenso à persecução. Se a questão é a aptidão do direito penal para lidar com ilícitos no mercado de capitais, veremos este problema brevemente adiante. $\mathrm{O}$ certo é que devemos ver nesta expansão mais sinais de desconforto que o direito 
penal sente face ao dinamismo do setor econômico, como já mencionamos reiteradamente.

Apesar das críticas que podem ser feitas à expansão do direito penal, podemos afirmar que é necessária a tutela do mercado de capitais. O capital mobilizado por esta estrutura afeta uma enorme parcela da população mundial e, como toda atividade humana, está vulnerável a abusos.

O próprio mercado é incapaz de se proteger dos riscos inerentes à atividade, posto que é dotado de brechas e falhas que dificilmente serão corrigidas sem a intervenção do direito (seja ele penal ou administrativo). O próprio mercado não pode impedir a existência da informação privilegiada, e o seu uso depende apenas do detentor, sendo sempre uma vantagem.

Ante o exposto, podemos tirar algumas conclusões importantes acerca da contextualização dos crimes contra o mercado de capitais, e consequentemente, do crime de uso indevido de informação privilegiada.

Inicialmente, que as mudanças sistêmicas e o fenômeno da globalização, que afetou drasticamente o mercado de capitais, criaram um novo cenário ao qual o direito se viu forçado a se adaptar.

Em seguida, que essa adaptação se deu através da expansão do direito penal, que até os dias de hoje sofre com controvérsias e continua crescendo e se transformando, tentando se moldar à realidade que a cerca.

Entendemos então que o crime de insider trading não pode ser analisado num vácuo, mas abarcando o seu contexto complexo e envolto de circunstâncias peculiares e ainda em desenvolvimento. 


\section{CAPÍTULO 2 - Análise do crime de insider trading}

Para entendermos corretamente o crime de uso indevido de informação privilegiada, devemos atentar para uma série de conceitos e particularidades do mundo do mercado de capitais. Como todo crime, tratase de uma conduta inserida num contexto, e quanto mais específico o contexto, mais devemos estar familiarizados com suas circunstâncias únicas.

Para tal, analisaremos a origem da legislação referente ao insider trading, levando em conta a enorme influência que a legislação dos Estados Unidos teve sobre a brasileira, incluindo as críticas que são feitas a essa influência.

Em seguida, faremos algumas breves considerações sobre as controvérsias que cercam o bem jurídico tutelado pelo tipo penal em questão, passando por uma análise detalhada do mesmo.

Então, abordaremos alguns conceitos essenciais que permeiam todo o contexto no qual o crime de uso indevido de informação privilegiada está envolto. Por se tratar de um cenário de mercado de capitais, faz-se mister analisarmos alguns conceitos societários.

Por fim, passaremos a algumas conclusões tanto sobre o crime de insider trading em si quanto à sua adequação para alcançar os objetivos do direito penal econômico.

\section{1 - Origens do insider trading}

Castellar traz um excelente resumo do surgimento do crime de uso indevido de informação privilegiada (tanto no Brasil quanto nos Estados Unidos), que utilizaremos como base de apoio (2008, pp.86-92). Iremos nos 
ater apenas ao necessário para entender o surgimento da repressão à conduta, não sendo de grande relevância um tratamento minucioso da questão para fins deste trabalho.

O autor explica que tudo se iniciou durante o New Deal (de 1933 a 1937), quando a crise econômica de 1929 ainda havia deixado seu impacto. Foi nesta época que o Securities Act of 1933 e o Securities and Exchange Act of 1934 surgiram, ambas as leis no intuito de regular o Mercado de Capitais. Ao perceber o potencial devastador que um mercado não regulado detinha sobre a economia do país, o governo norte-americano se viu na obrigação de produzir uma legislação pertinente.

Foi o Securities and Exchange Act of 1934 que criou a famosa Securities and Exchange Commission, agência federal reguladora do mercado de capitais cuja versão brasileira seria a Comissão de Valores Mobiliários.

A respeito da instrução 10b-5, Castellar cita Müssnich e ensina que:

\begin{abstract}
"Mais adiante surge a instrução 10b-5, de 1942, que proíbe aos administradores transacionarem com os valores mobiliários de suas companhias se eles possuírem qualquer informação relevante que não seja pública, obtida no exercício do cargo, vedando qualquer operação na qual uma parte careça de informação que a outra parte deveria ter divulgado, abrangendo, portanto, não só as operações efetuadas por administradores, mas também operações efetuadas por terceiros vinculados aos administradores, seja qual for a origem do vínculo e ainda a qualquer pessoa física ou jurídica que adquire a informação relevante em virtude da sua proximidade com a companhia" (2008, p.88).
\end{abstract}

No Brasil, alguns diplomas legais começaram a tentar inserir a repressão ao insider trading de forma relativamente imprecisa (como o artigo $3^{\circ}$, inciso X da Lei $\left.{ }^{\circ} 4.728 / 1965\right)$. É somente com o advento da Lei $\mathrm{n}^{\circ} 6.404 / 1976$ (a Lei da S.A.), em seu artigo $157, \S^{\circ}$, que temos o primeiro enquadramento concreto e minimamente viável para insider no âmbito civil e administrativo. No mesmo ano, foi promulgada a Lei $\mathrm{n}^{\circ} 6.385 / 1976$, que traz disposições sobre o mercado de capitais e cria a CVM. 
É somente em 2001 que a tipificação penal da conduta de insider trading surge, através da Lei $\mathrm{n}^{\circ} 10.303$. O referido diploma legal traz o Capítulo VII-B à Lei nº.385/1976, e em seu artigo 27-D cria a figura do crime de uso indevido de informação privilegiada.

Feitas as considerações acima acerca da importação legislativa que nosso ordenamento jurídico fez do insider trading norte-americano, nos permitimos fazer algumas críticas a essa adoção.

Inicialmente, concordamos com Castellar, que aponta que a cultura e o contexto dos Estados Unidos são completamente diferentes da realidade brasileira (2008, p.93). No caso, o ordenamento brasileiro não se inspirou na legislação norte-americana, mas quase que a copiou completamente. O primeiro problema que observamos, nesse caso, é que o sistema de direito norte-americano é extremamente diferente do brasileiro.

Ainda seguindo no raciocínio de Castellar, vemos que a legislação americana, relativamente vaga em suas definições, se assenta no sistema da common law, regido principalmente pelo sistema de precedentes. Estando relativamente acorrentado à jurisprudência, o juiz não tem brecha para abusar da relativa vagueza das definições do tipo penal de crime de uso indevido de informação privilegiada (2008, p.93).

No caso do ordenamento brasileiro, no entanto, estamos diante do sistema de civil law. Um dos aspectos principais do direito penal é a quase absoluta proibição de qualquer vagueza no tipo penal, devendo este ser específico. Com isso, fazemos da conclusão do autor a nossa: há grande perigo em importar uma legislação baseada no sistema da common law sem adequá-la propriamente. 


\section{2 - Bem jurídico tutelado pelo crime de uso indevido de informação privilegiada}

Como todo crime contra o mercado de capitais, o crime de insider trading sofre com uma incapacidade da doutrina brasileira de convergir numa definição clara. É a situação de toda legislação que abarca um fenômeno relativamente novo, e por isso iremos traçar um panorama geral das teorias dominantes, inserindo nossas conclusões logo em seguida.

O bem jurídico tutelado pela norma penal deve sempre estar relacionado a algum tipo de lesão, pelo próprio princípio da lesividade. Não podemos entender que exista tutela sem lesão efetiva ao bem jurídico, motivo pelo qual não basta elucidarmos qual o bem jurídico tutelado pelo crime de uso indevido de informação privilegiada, mas também fazermos uma análise crítica quanto à sua necessidade. Dito isso, não abordaremos a extensa e complexa discussão da (in)constitucionalidade dos crimes de perigo abstrato.

No caso, o bem jurídico dos crimes contra o mercado de capitais de forma geral se divide em algumas correntes principais. São as da tutela: (i) patrimonial dos investidores, (ii) da igualdade entre os investidores, (iii) do correto funcionamento do mercado de capitais, (iv) dos interesses da sociedade emissora de valores mobiliários, e (v) da confiança dos investidores.

A primeira entende que o bem jurídico tutelado no crime de insider trading seguiria a teoria pessoal do bem jurídico (nos moldes desenvolvidos por Hassemer), tratando de um bem supraindividual de interesses individuais do público investidor como um todo (ALONSO, 2009, pp. 116-117). Esta abordagem desenvolve uma noção interessante do bem jurídico tutelado, mas não acompanhamos o autor em seu entendimento, posto que entendemos que o crime de insider trading não visa tutelar apenas o patrimônio dos 
investidores, como também o das sociedades emissoras de valores mobiliários. Trata-se de um tipo penal relativamente amplo, e por mais que concordamos que os investidores são um dos alvos principais da tutela, não acreditamos ser o único.

A segunda corrente se assenta na noção de que deve haver uma espécie de igualdade formal entre os investidores. Evidentemente, não sendo possível uma igualdade material, pelo menos se buscaria a igualdade formal para que o ponto de partida do investidor médio seja justo. Aqui enxergamos que tal igualdade é um elemento da proteção em questão, não sendo suficiente para justificar, por si só, a tutela repressiva do direito penal.

A terceira corrente entende que o crime de insider trading não impede apenas a igualdade formal, mas desestabiliza o próprio mercado de capitais com sua perpetuação (PROENÇA apud CASTELLAR, 2008, p.104). Logo, o bem jurídico seria o próprio correto funcionamento do mercado de capitais.

A quarta corrente se traduz no resguardo às companhias emissoras de valores mobiliários, na medida em que são estas que possibilitam o funcionamento do mercado de capitais e que se expõe ao mesmo. A crítica que fizemos à primeira corrente se repete aqui, posto que não podemos entender que apenas as sociedades emissoras de valores mobiliários sofrem com o crime de insider trading, especialmente porque elas estão revestidas de proteções específicas quanto à quebra de sigilo por parte dos insiders.

Por fim, a quinta corrente segue o entendimento de que a prática reiterada da conduta de insider trading removeria a confiança que os atores do mercado de capitais têm no mesmo, uma vez que os investidores não poderiam se fiar às informações e condições conhecidas do mercado em que atuam. 
Feitas as breves considerações acima, entendemos que apesar de não haver sinal de consenso quanto ao bem jurídico tutelado pelos crimes contra o mercado de capitais, é quase unânime que deve haver tutela do mercado de capitais em si. Trata-se de parte integrante do Sistema Financeiro Nacional, que afeta profundamente a economia e, consequentemente, milhões de brasileiros e estrangeiros.

Por mais que devamos evitar a tutela de bens e instituições demasiadamente amplos, fica evidente que crimes contra o mercado de capitais são complexos e abrangentes. Com isso em mente, nos aproximamos à corrente que entende que o bem jurídico tutelado pelo crime de insider trading é o correto funcionamento do mercado de capitais. No entanto, fazemos uma breve ressalva aparentemente semântica, porém com uma diferença essencial.

Concordamos, em essência, com a corrente doutrinária referida, mas entendemos que se trata menos de uma tutela do funcionamento em si, e mais da integridade do mercado de capitais. O funcionamento em si do mercado, ao nosso ver, pode ocorrer com a prática do crime de insider trading. António J. Monroy Antón apresenta argumentos alegando que, possivelmente, a prática de insider trading deveria ser legalizada, posto que não traz mais malefícios do que sua proibição para o mercado (MONROY apud CASTELLAR, p.114). Neste sentido, não faria sentido falarmos de tutela do correto funcionamento do mercado de capitais através da criminalização da conduta descrita no tipo penal, posto que tal funcionamento não ficaria impedido.

A integridade deste mercado, no entanto, estaria comprometida. $\mathrm{O}$ insider trading não impede que o mercado de capitais funcione corretamente, tanto é que a conduta acontece independentemente de ser criminalizada. A tutela em si visa mais, ao nosso ver, resguardar ao máximo a integridade do 
mercado, posto que cada realização da conduta de insider trading danifica o mercado como um todo.

Neste sentido, entendemos que todas as correntes mencionadas têm fortes argumentos, que consideramos oportuno integrar. A integridade do mercado de capitais depende de igualdade formal, de proteção ao patrimônio dos investidores, de proteção às sociedades emissoras de valores mobiliários, e da confiança no mercado. Entendemos que a criminalização da conduta de insider trading visa resguardar todos estes elementos através da tutela da integridade do mercado em si. Como mencionamos antes, nenhum dos elementos mencionados justifica, por si só, a intervenção penal. A intervenção penal por viés patrimonialista não nos parece adequada, principalmente com ausência de violência (apesar de a visão ser reforçada no nosso Código Penal). O aspecto da tutela patrimonial estaria suficientemente resguardada através do direito civil ou administrativo, não justificando a intervenção penal por si só.

Sendo assim, percebemos que a tutela penal, se adequada (ponto a ser discutido mais adiante), somente se justifica com uma confluência dos argumentos supracitados, englobando uma proteção à própria integridade do mercado de capitais, que só seria resguardada com a criminalização da conduta por ser considerada danosa sistemicamente, e não especificamente. Entendemos a controvérsia que tal visão levanta, mas é justamente essa a premissa de crimes de perigo abstrato: criminalizar com uma lógica sistêmica. Ao nosso ver, se entendermos que tal criminalização é adequada, então também devemos admitir a tutela de bem jurídicos mais amplos.

\section{3 - Análise do tipo penal}

\subsection{1 - Objeto do crime}


O crime de insider trading está tipificado no artigo 27-D da Lei n6.385 de dezembro de 1976, e estipula:

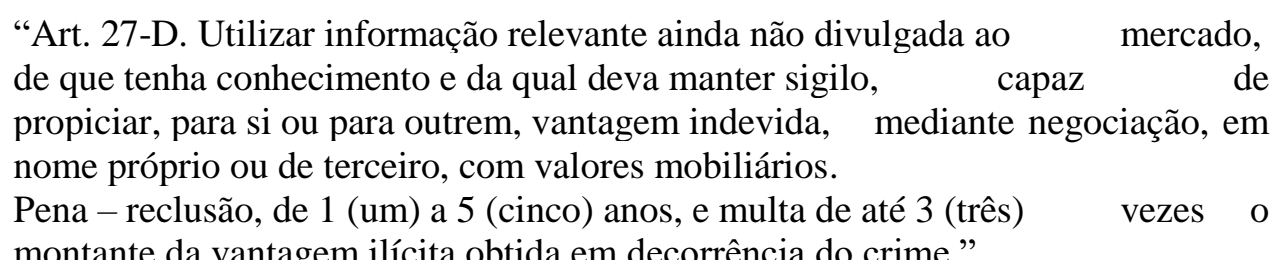
montante da vantagem ilícita obtida em decorrência do crime."

Lendo o tipo penal com atenção, percebemos que a configuração do crime depende de 4 elementos principais.

O primeiro é a utilização de informação relevante mediante negociação com valores mobiliários. No caso, entendemos que 'informação relevante' é aquela que traduz um fato ou ato relevante, conceito que abordaremos em mais detalhes em item posterior. Também é necessário que a utilização seja feita através de negociação, e que esta seja feita com valores mobiliários. Significa que a tipificação é específica ao contexto do mercado de capitais, e a negociação em dinheiro não enseja o tipo penal. Este ponto será melhor tratado quando abordarmos a questão do agente.

Em segundo lugar, a informação não deve apenas ser relevante, mas também não deve ter sido divulgada ao mercado. Aqui rechaçamos as correntes que não empregam a análise objetiva do texto legal, que estipula que a informação se torna pública quando divulgada à imprensa (artigo 157, $\S^{\circ}$ da Lei $\left.n^{\circ} 6.404 / 1976\right)$. Um tipo penal que já sofre com problemas de pacificação de interpretação não precisa de dúvidas superficiais, e a publicidade da informação se constrói a partir do seu acesso pelo público, independentemente do tempo de divulgação. Assim entendemos pois esperar que a informação seja assimilada pelo público é completamente contraditório com a lógica do mercado de capitais, que não pode ser pausado para que investidores tomem decisões. Também não incide a corrente intermediária, que alega ser necessário um lapso de tempo mínimo a partir da publicação, posto que insere mais dúvidas abstratas sobre qual seria a duração ideal de 
tempo. No fim, acreditamos que não há resposta pacífica e ideal acerca de lapso temporal para efetiva divulgação da informação ao público, devendo prevalecer o critério objetivo estabelecido pelo artigo $157, \S 4^{\circ}$ do dispositivo legal referido.

Em terceiro lugar, o artigo menciona especificamente que a conduta só é típica se a informação em questão era resguardada por um dever de sigilo. Neste aspecto, o dever de sigilo em si não é específico a um tipo de agente, mas uma característica concedida com base no caso concreto e atribuída por lei.

Em quarto lugar, o tipo penal estabelece que a informação em questão deve ser capaz de propiciar vantagem indevida. Aqui entendemos que uma questão de semântica se faz importante. $\mathrm{O}$ artigo não menciona que o insider deve negociar a informação com o intuito de obter vantagem indevida, e sim que o mero fato de a informação ser capaz de propiciar tal vantagem configura crime de insider trading. Esta consideração será de suma importância para definirmos o tipo subjetivo do crime.

Percebemos que o tipo objetivo do crime de uso indevido de informação privilegiada é complexo, sendo composto de diversos elementos essenciais cuja definição não é pacífica na doutrina. Cada uma destas controvérsias terá efeitos importantes na definição do crime como um todo, questões que trataremos em detalhes a seguir.

\subsection{2 - Tipo subjetivo - dolo e culpa}

A questão de o crime de insider trading ser crime material ou crime formal é matéria de tipo objetivo. Porém, entendemos que sua abordagem é essencial para discutirmos o tipo subjetivo do delito, motivo pelo qual 
preferimos introduzir a discussão no presente tópico ao invés de acoplá-la à leitura do tipo que fizemos acima.

Autores que entendem tratar-se de crime material (Castellar, Eizirik, Carvalhosa) seguem a lógica de que é necessária a obtenção de vantagem indevida por parte do agente. Sendo assim, a utilização da informação privilegiada para negociar com valores mobiliárias seria a conduta, e a obtenção da vantagem indevida o resultado naturalístico necessário para que seja configurada a consumação do delito. Não tendo sido a vantagem obtida por circunstâncias alheias à do agente, haveria a tentativa por conta da incidência do artigo 14, inciso II do Código Penal.

Por outro lado, certos doutrinadores entendem que se trata de crime formal (Alonso, Pedrazzi, Costa Junior, De Sanctis) posto que o tipo penal não prevê o resultado naturalístico (obtenção da vantagem), e sim apenas a utilização da informação, que em si deve ter capacidade de propiciar vantagem indevida. Neste ponto, fazemos uma ressalva importante.

A esmagadora maioria da doutrina que considera o crime de insider trading como sendo crime formal entende que o dolo específico de obter vantagem indevida deve estar presente para que haja consumação do crime. Neste ponto, com todo respeito aos ilustres juristas, discordamos.

Uma leitura atenta do tipo penal nos aponta que o dolo necessário para que haja consumação do crime é o de utilizar a informação privilegiada para negociar com valores mobiliários. O texto legal apenas menciona que a informação utilizada deve ser capaz de propiciar vantagem indevida, não que o agente deve estar munido deste dolo específico para cometer o crime. A nossa lógica é que o tipo penal estabelece a potencialidade lesiva da informação para evitar uma criminalização com afronta direta ao propósito penal (que seria a de evitar criminalizar condutas não nocivas), mas não há 
indicação alguma de que a vantagem indevida deva estar presente no desígnio do agente.

Ao nosso ver, não há que se falar em crime material, posto que o tipo penal em questão não prevê resultado naturalístico. Assumir que a capacidade de a informação propiciar vantagem indevida é equivalente a afirmar que o crime somente se consuma se houver dolo de obtenção de vantagem indevida é uma interpretação além de um texto legal que não apresenta lacuna. Neste sentido, entendemos que trata-se de crime formal, sendo necessária a utilização de informação privilegiada para negociar valores mobiliários para que a o crime esteja consumado.

Como é cediço no nosso ordenamento jurídico, a interpretação do tipo penal quanto à intenção do legislador ou às lacunas deve ser utilizada como último recurso. Levando em conta que os crimes contra o mercado de capitais já carecem de clareza e especificidade, não vemos por que interpretar um dolo específico que o texto legal claramente não menciona.

Se estamos diante de um erro do legislador ao mencionar a vantagem indevida apenas quando qualifica a informação privilegiada, não nos parece relevante para a análise do tipo subjetivo. Não acreditamos se tratar de um caso que demanda interpretação para além da literalidade do texto, que é claro.

Cabe, ainda, mencionarmos que o disposto no artigo $155, \S 4^{\circ}$ da Lei nº.404/1976 prevê a necessidade de auferimento de vantagem indevida para que se configure a prática de insider trading, como consequência do dever de lealdade previsto no próprio artigo 155 . Não acreditamos que tal fato seja prova da necessidade de obtenção de vantagem indevida na seara penal, muito pelo contrário, e cabe fazermos este apontamento. 
A norma acima mencionada trata da seara administrativa, distinta e independente do direito penal. Com isso, aplicar o auferimento de vantagem indevida como elemento típico do crime previsto no artigo 27-D da Lei $\mathrm{n}^{\circ} 6.385 / 1976$ somente por estar previsto em norma administrativa seria fazer uma interpretação analógica, o que não é permitido pela nossa legislação no caso em questão. Não há omissão, ambiguidade, ou vagueza no tipo penal do crime de uso indevido de informação privilegiada. Por algum motivo (ou erro), o legislador não quis que o auferimento de vantagem indevida fosse elemento essencial para a configuração do crime de insider trading, e o tipo penal não deixa dúvidas sobre isso. Se faria mais sentido tal elemento estar presente, trata-se de outra discussão. O fato é que transladar uma condição da conduta da seara administrativa para a penal com uma interpretação analógica não é permitido pela nossa legislação, em virtude da ausência de lacuna no tipo penal, não havendo necessidade de auferimento (ou tentativa) de vantagem indevida para que haja a configuração do crime.

Outro ponto que corrobora o entendimento acima exposto é o artigo 27-C da Lei nº.385/1976. Trata-se do crime de manipulação do mercado, e seu tipo penal prevê o dolo específico do agente de obter vantagem indevida ou lucro. Ambos os crimes de insider trading e manipulação de mercado foram inseridos na Lei $n^{\circ} 6.385 / 1976$ pela Lei $n^{\circ} 10.303 / 2001$. Sendo assim, a conclusão lógica e presumida é que, se o legislador optou por tornar o dolo específico de auferir vantagem indevida um elemento necessário para que haja a configuração de crime de manipulação de mercado, mas não elencou esse elemento para a configuração do crime de insider trading, a intenção é clara: não há necessidade de dolo específico de auferir vantagem indevida no insider trading. Novamente, aqueles que arguirem que se trata de erro ou descuido do legislador estão em outra discussão. Com a redação atual e no nosso ordenamento jurídico, nos parece razoável concluir que o tipo penal descrito no artigo 27-D da Lei nº.385/1976 não requer o dolo específico de 
auferir vantagem indevida para que haja configuração do crime, e sim apenas que a informação utilizada seja capaz de propiciar essa vantagem.

Seguindo adiante, cabe fazermos um breve apontamento quanto à possibilidade de modalidade culposa e tentada do crime de insider trading. Como o artigo 18 do Código Penal bem estipula, não há punição pela modalidade culposa salvo previsão legal. Como não há qualquer previsão deste tipo acerca do crime de insider trading, entendemos que sua modalidade culposa não é punível.

Quanto à modalidade tentada, entendemos que a situação é mais complexa. Por definirmos o crime de insider trading como crime formal, fica evidente que a tentativa, a princípio, só é possível se estivermos diante de um crime plurissubsistente. Com isso, apontamos que há um iter criminis que pode ensejar a modalidade tentada do crime.

Se o agente, por exemplo, tenta utilizar a informação para negociar valores mobiliários mas, ao enviar o comando ao sistema da bolsa de valores pertinente, não consegue efetuar a negociação por conta de uma pane ou um bug no sistema em questão, haveria tentativa? A conduta foi executada, posto que o agente utilizou informação privilegiada para negociar valores mobiliários, porém a negociação não pôde ser concluída por circunstâncias alheias à sua vontade.

Dito isso, é penosa a tarefa de argumentar que existe um iter criminis claro, e o exemplo acima citado serve apenas como tentativa de lançar a discussão. Para definir tal questão com mais acurácia, deveríamos adentrar a nova realidade que sistemas de informação e a internet trouxeram: a de atos que acontecem em frações de segundos, porém são divisíveis em sua própria esfera de tempo. Por mais que a conduta descrita no artigo 27-D da Lei nº.385/1976 pareça se consumar instantaneamente, percebemos que existe 
a possibilidade, por mais ínfima que seja, que o agente tente negociar valores mobiliárias e não consiga fazê-lo. Esta análise exige um debruçamento sobre o passo-a-passo da transferência de dados através de redes e provedores que foge ao escopo deste trabalho.

\section{4 - Agente e vítima no insider trading}

\subsection{1 - Agente}

Como prevê claramente o tipo penal do crime de insider trading, o agente deve estar munido de um dever de sigilo sobre a informação privilegiada. Portanto, seguimos o entendimento majoritário no sentido de entender que se trata de crime próprio, posto que o dever de sigilo é elementar do tipo. Sendo assim, também entendemos que coautores e partícipes devem responder em razão do artigo 30 do Código Penal.

Faz-se mister a observação de que, desde que a informação tiver capacidade de propiciar vantagem indevida, for relevante, não tiver sido divulgada ao mercado, e for de conhecimento do agente, a simples presença de dever de sigilo caracteriza a autoria. O tipo penal não especifica que tal dever deva advir da lei, por mais que essa seja a situação padrão na realidade dos casos. Na prática, no entanto, a esmagadora maioria dos casos atinge insiders que adquiriram o dever de sigilo violado através de disposição legal, como explica Castellar:

"[...] a quem a lei atribui o dever de lealdade, quais sejam: os administradores (art. 155); b) os conselheiros e diretores (art. 145); c) os integrantes de órgão técnicos e consultivos (art. 160); d) os subordinados ou terceiros de confiança dos administradores, apelidados tippees (pessoas que recebem e usam ou passam adiante tais informações, inclusive jornalistas - art. $155, \S 2^{\circ}$ ); e) os membros do conselho fiscal; f) os acionistas controladores e minoritários (art. 22, V, da Lei $\left.\mathrm{n}^{\circ} 6.385 / 76\right)$, g) as pessoas que prestam serviços jurídicos ou contábeis à companhia, que também estão investidas por lei, do dever de sigilo; h) os agentes privados que atuam no âmbito do mercado de valores mobiliários (profissionais de distribuidores e corretoras de valores mobiliários e de mais instituições que tenham por finalidade social concessão de crédito, investimento e financiamento, além das administradoras de mercado de balcão organizado e bolsas de valores e de 
mercadorias e futuros); i) os agentes públicos encarregados da fiscalização do setor (integrantes da CVM, BACEN e CMN) e também aquelas referidas na Instrução CVM 358 (art. 13, $\S \S 1^{\circ}$ e $2^{\circ}$ )" (2008, pp. 120-121).

Prova disso é que existe o chamado dever contratual de sigilo, que é consequência natural da realização de certos serviços que, por sua natureza, expõe seus prestadores a informações que devem ser mantidas sigilosas (AFONSO, 2009, p.133).

\subsubsection{1 - Insider primário}

O insider primário é aquele que se enquadra diretamente na previsão do artigo 27-D da Lei nº.385/1976. É o insider principal e essencial ao cometimento do crime, posto que é aquele que tem proximidade com a informação privilegiada. Um insider que não tem acesso direto à informação não deverá ser considerado, de regra, como primário.

Importante ressaltarmos que a CVM entende que, além de ter acesso direto à informação, o insider primário é aquele que tem capacidade suficiente para entender as possibilidades e consequências que o uso de tal informação pode gerar (CVM, 2016, p.21).

Por sua própria posição de dever de sigilo, essa capacidade deve ser presumida. Se o agente não tiver capacidade de entender minimamente as consequências do uso da informação sobre a qual deve guardar sigilo, então não se justifica a responsabilidade que lhe é concedida com o resguardo da informação. Entendemos então que, pela própria lógica, deve ser presumida a capacidade para entender as consequências de utilizar informação privilegiada para negociar com valores mobiliários.

\subsubsection{2 - Insider secundário}


O insider secundário, por sua vez, é aquele que recebe a informação de um insider primário, quer voluntaria ou involuntariamente. Na doutrina, são comumente denominados tippees. Entende-se que existem três espécies de insiders secundários.

O primeiro é aquele que recebe a informação por acidente, e é denominado por certos autores e pela CVM de insider acidental (CVM, 2016. p.22). Aqui não haveria incidência do crime de insider trading, na nossa opinião, posto que e o insider acidental não tem dever de sigilo ou de lealdade, não adquiriu a informação infringindo nenhum dispositivo, e não está em conluio com o insider primário (artigo 29 do Código Penal) se resolver negociar com valores mobiliários com base no conhecimento adquirido acidentalmente.

O segundo é o insider que obtém a informação através de meios ilegais e sem estar em conluio com o insider primário. No caso, não entendemos pela incidência do artigo 27-D da Lei nº.385/1976, pelos mesmos motivos que ensejam a não incidência do dispositivo no caso de insider acidental. Esta segunda categoria de insider secundário responderá pelos crimes que possibilitaram a captura da informação e quaisquer outros referentes às consequências de tais condutas, mas não há transferência da elementar de tipo de dever de sigilo se o insider primário não existir (não utilizar a informação para negociar com valores mobiliários), posto que este não teria cometido o núcleo do tipo.

Por fim, a terceira espécie é o insider que age como coautor ou partícipe do crime de insider trading. Aqui não há mistérios, posto que há participação dolosa no cometimento do crime, e os artigos 29 e 30 do Código Penal preveem a punibilidade do insider secundário nestas circunstâncias.

\subsection{2 - Vítima}


O sujeito passivo do crime de insider trading não é tema de ampla discussão na doutrina. Sua definição não parece muito importante, mas acreditamos que sua falta de relevância revela mais um desconforto com certos elementos do crime em questão do que com uma efetiva desnecessidade do conceito.

Assim entendemos pois a definição do sujeito passivo deverá estar atrelada, logicamente, ao bem jurídico protegido. Como tal discussão é fruto de forte divergência na doutrina, fez-se conveniente não se alongar a respeito de quem seria a vítima.

Por se tratar de crime do direito penal econômico, o insider trading afeta uma enorme parcela da sociedade. Que esta é vítima está subentendido por se tratar de crime (todo crime fere a sociedade de alguma maneira), sendo irrelevante para nossa definição. Nos resta, então, o Estado, os investidores, as sociedades emissoras de valores mobiliários, e o resto daqueles que são afetados pela conduta.

Entendemos que a vítima primária do insider trading é o Estado, posto que tal posição é congruente com o bem jurídico que escolhemos: a integridade do mercado de capitais. É o Estado que deve zelar por essa integridade, e ele sofre os efeitos de forma macroestrutural. $\mathrm{O}$ investidor sofre os efeitos do crime, mas não é o principal protegido pela tutela penal.

Dito isso, fica evidente que a conduta do insider trading afeta diretamente uma enorme parcela dos investidores, posto que muitos daqueles que detêm valores mobiliários veem seu patrimônio diminuir em razão da conduta. Neste sentido, entendemos que os investidores diretamente afetados pela conduta são vítimas secundárias do delito. 
Importante ressaltarmos que podem ser considerados vítimas os investidores que não sofreram diretamente com a conduta do insider, porém enquadrados na categoria de 'sociedade', e não como uma categoria à parte de vítima. Assim é porque estes investidores não sofreram diretamente com a prática do delito, e sim com a depreciação da integridade do mercado de capitais de forma geral.

Por fim, importante ressaltarmos que as sociedades emissoras de valores mobiliários passam pelo mesmo filtro de sujeito passivo que aplicamos aos investidores. Aquelas diretamente afetadas pelo delito são vítimas secundárias, e aquelas indiretamente afetadas (pela perda de integridade do mercado) não são vítima propriamente dita, e sim parte da sociedade, que foi lesada pela conduta.

\section{5 - Conceitos relevantes}

Por mais que o foco do presente trabalho seja a abordagem penal do insider trading, entendemos que se trata de um delito complexo envolto num cenário extremamente específico e desenvolvido. Com isso, faz-se necessária uma breve análise de certos conceitos fundamentais para a devida contextualização e compreensão do delito.

\subsection{1 - Fato relevante}

Como a doutrina já se debruçou suficientemente sobre a conceituação de fato relevante, faremos apenas um breve apanhado do instituto de acordo com sua conceituação no âmbito do ordenamento jurídico brasileiro, fazendo uma passagem pela noção norte-americana do mesmo.

O termo 'fato relevante' está previsto na instrução n⿳358 de 2002 da CVM, em seu artigo $2^{\circ}$, que estipula: 

"Art. 2o Considera-se relevante, para os efeitos desta Instrução, qualquer decisão
de acionista controlador, deliberação da assembléia geral ou dos órgãos de
administração da companhia aberta, ou qualquer outro ato ou fato de caráter
político-administrativo, técnico, negocial ou econômico-financeiro ocorrido ou
relacionado aos seus negócios que possa influir de modo ponderável: I - na cotação
dos valores mobiliários de emissão da companhia aberta ou a eles referenciados; II
- na decisão dos investidores de comprar, vender ou manter aqueles valores
mobiliários; III - na decisão dos investidores de exercer quaisquer direitos inerentes
à condição de titular de valores mobiliários emitidos pela companhia ou a eles
referenciados."

$\mathrm{O}$ artigo segue dando vinte e dois exemplos de ato ou fato relevante em seu parágrafo único. Cabe apontarmos que, como bem afirma Eizirik, a nossa legislação (artigo 155, parágrafo único da Lei das S.A) considera fato relevante aquele "capaz de influir, de modo ponderável, na cotação dos valores mobiliários" (2011, p.558).

Nos Estados Unidos, o termo foi foco de discussões acerca do crime de insider trading como um dos elementos principais para definir a ocorrência ou não do ilícito, e entendemos ser importante fazermos algumas observações pontuais acerca da jurisprudência norte-americana.

O caso mais importante para fins de discussão do que seria fato relevante nos Estados Unidos é 'SEC v. Texas Gulf Sulphur Company'. A empresa em questão estava em processo de exploração mineral no Canadá, iniciada com base em dados preliminares promissores. Diversos dos responsáveis pela aferição do potencial da região, peritos da empresa, concluíram que o local em questão era rico em minérios valiosos. Tal informação não foi tornada pública, e diversos funcionários, diretores, e pessoas conectadas à empresa começaram a comprar ações da TGS Company. Após aproximadamente três dias, a companhia lançou a informação ao público, e essa publicidade foi efetivada um dia após o lançamento.

A Securities and Exchange Commission entrou com ação, acusando os réus de insider trading. Estes alegaram que a informação que não havia 
sido publicada anteriormente (da descoberta dos minérios) não era relevante (“material information"), e que essa ausência de relevância os isentava da obrigação de publica-la de pronto.

A corte seguiu o entendimento da SEC no sentido de considerar a conduta dos réus como insider trading, tendo em mente principalmente o comportamento destes, completamente contrário à alegação de defesa. Por terem adquirido ações, por não tornarem a informação pública propositalmente, e pela compra de ações ter acontecido enquanto a informação não era pública, os réus estariam entrando em contradição direta com sua alegação principal de que a informação não era relevante.

Os réus também alegaram que a divulgação da informação traria problemas quanto à aquisição dos direitos de minerar naquele local, argumento que foi rechaçado pela corte, que entendeu que os responsáveis não estavam obrigados a divulgar a informação anteriormente, e sim de se abster de negociar com valores mobiliários no meio tempo ('disclose or abstain' do direito norte-americano, desenvolvido pela própria SEC).

No caso, a corte entendeu como oportuno definir o que seria fato relevante ('material information') da seguida forma:

\footnotetext{
"Sendo assim, fatos relevantes incluem não somente informações divulgando ganhos e distribuições de uma empresa, mas também aquelas informações que afetam o futuro provável da empresa e aquelas que podem afetar o desejo de investidores de comprar, vender, ou guardar valores mobiliários emitidos pela empresa" (SEC v. Texas Gulf Sulphur Co., 401 F.2d 833, 849 - 2d Cir. 1968 tradução nossa).
}

Ao nosso ver, a definição dada pela corte foi precisa e adequada. O fato relevante se traduz, concretamente, numa informação que alteraria o desejo do investidor comum. Se assim não fosse, não haveria lesividade, posto que a informação sequer seria privilegiada em sua essência, pois não afetaria investidor algum. 
Sem nos alongarmos demasiadamente no assunto, fazemos apenas umas considerações finais. Em razão de nosso conceito de insider trading ter sido fortemente influenciado pelo direito norte-americano, acreditamos ser de extrema relevância o desenvolvimento histórico-jurisprudencial da figura no ordenamento dos Estados Unidos, principalmente porque este tem mais experiência do que o ordenamento brasileiro com a questão.

Sendo assim, devemos observar que, a partir do caso 'SEC v. Texas Gulf Sulphur Company', a SEC passou a aplicar a 'Rule 10b-5' (que retém o conceito de fato relevante) com mais rigor, processando agressivamente aqueles que feriam o dispositivo, expandindo a aplicação do mesmo a situações cada vez mais abrangentes. Tal expansão foi fortemente freada pelo Ministro Powell ao entrar para a Suprema Corte dos Estados Unidos, que começou a questionar o alcance da interpretação da legitimidade da SEC para processar como vinha fazendo desde a decisão de 'SEC v. Texas Gulf Sulphur Company', e da aplicação abrangente da 'Rule 10b-5' (HOHENSTEIN, 2006).

A lição que podemos tirar desta trajetória é que devemos atentar para o poder que a CVM pode ou não adquirir dependendo da interpretação dos tribunais brasileiros. Encontrar um equilíbrio ao definir o que seria fato relevante para fins de insider trading é uma tarefa mais trabalhosa do que aparenta, como vemos na jurisprudência norte-americana, justamente pela complexidade do contexto. Tal ressalva se aplica, evidentemente, à esfera penal.

Se a definição da abrangência do termo é difícil no âmbito administrativo, pior é na seara penal, em virtude da clareza e especificidade que o tipo penal requer para ser aplicável. 
É evidente que há muito a ser analisado e estudado a respeito, e que não chegamos perto de traçar um panorama detalhado da jurisprudência norte-americana, mas achamos oportuno fazermos esta breve passagem pelo assunto, no intuito de captar indícios de possíveis desafios na prática da definição de fato relevante para fins de insider trading como conduta punível de fato.

\subsection{2 - Dever de diligência}

O dever de diligência, como bem aponta a doutrina, é um conceito vago que vem do 'standard of care' norte-americano, que em si decorre de um dever de cuidado ('duty of care'). Está previsto no artigo 153 da Lei nº.404/1976.

A lógica que permeia esta instituição é a de que a pessoa com o dever de cuidado (no caso da sociedade anônima, o administrador da companhia) deve alcançar um padrão mínimo de cuidado e probidade em sua atuação.

Reproduzimos a seguir crítica impecável de Castellar quanto à importação do conceito para o ordenamento jurídico brasileiro:

"[...] o princípio em que se funda o dever de diligência, cujas raízes primárias
remontam ao direito romano, torna-se insuficiente na teoria institucionalista em
que se assentam as sociedades anônimas. A figura de um bom administrador de
companhia não se compraz com a do bônus pater famílias, do homo medius ou do
r[e]asonable man dos anglo-saxões. O chamado homem normal, tomado, na
doutrina de Hungria, "como símbolo e medida de diligência ordinária", não estará
necessariamente provido de capacitação adequada para gerir uma sociedade
anônima" (2008, p.96). Expandindo a definição rudimentar de dever de diligência que o artigo 153 da Lei nº.404/1976 traz, Flávia Parente elenca cinco deveres que decorrem diretamente deste: (i) de se qualificar para o exercício da função, (ii) de bem administrar, (iii) de se informar, (iv) de investigar, e (v) de vigiar (2005, pp.102-126). 
O primeiro está diretamente relacionado com a capacidade do administrador da companhia, isto é, no aprimoramento contínuo das habilidades que são relevantes e úteis para a sua função. Entende-se, aqui, que o administrador não pode somente gerir o negócio com atenção e cuidado, mas ter uma posição proativa quanto à contribuição que pode fazer ao desenvolvimento do mesmo, devendo haver especial atenção às capacidades técnicas do administrador para bem se enquadrar na sua função.

O segundo dever se traduz na conduta do administrador ao gerir o negócio, que deve estar sempre alinhada com o interesse da companhia (PARENTE, 2005, p.111). Este dever é um reflexo da posição do administrador, na medida em que impõe ao mesmo os objetivos da companhia tanto como propósito a alcançar quanto como limite a respeitar. Entendemos que se trataria de uma espécie de personificação da empresa na figura do administrador, que deve administrar buscando realizar os interesses da companhia, e não os seus próprios como administrador da mesma.

O terceiro trata do dever de informar que, como o próprio nome indica, implica na necessidade do administrador de se manter a par de todas as circunstâncias necessárias para uma administração eficiente da companhia. Neste sentido, Parente explica:

\footnotetext{
"Vale dizer, caso tenham se informado de maneira adequada, que os administradores não poderão ser responsabilizados caso as decisões por eles tomadas impliquem algum prejuízo para o patrimônio social.

Com efeito, como exposto anteriormente, a obrigação dos administradores é de meio e não de fim, motivo pelo qual, se eles cumpriram com o dever de se informar razoavelmente antes da tomada de alguma decisão a respeito do negócio social, não podem ser responsabilizados pelo descumprimento do dever de diligência" (2005, p.119).
}

O quarto dever é o de investigar, ou seja, de administrar com um olhar crítico e atencioso aos detalhes das informações e dos fatos que lhe são apresentados (PARENTE, 2005, p.126). Aqui percebemos o 
desenvolvimento do dever de diligência que Parente faz, posto que é no dever de investigar que vemos uma visão mais abrangente da figura do administrador. Quando alegamos que não basta que o administrador aja como pessoa proba e cuidadosa é, ao nosso ver, o dever de investigar que personifica tal ideia. $\mathrm{O}$ conceito originário de dever de diligência faz alusão a uma figura passiva, que apenas age corretamente e se contenta com isso. Quando a autora entende que o dever de investigar é um desdobramento do dever de diligência de forma geral, fica evidente que ela qualifica o administrador como uma pessoa que deve estar ativamente defendendo os interesses da companhia. Não se trata mais de um pater famílias exercendo poder, mas de um verdadeiro guardião ativo dos interesses da companhia, que procura analisar criticamente o quadro em que a companhia se apresenta, sempre buscando possíveis falhas e melhorias a serem feitas.

É nosso entendimento que o quinto dever é quase que uma subcategoria do quarto. O dever de vigiar é consequência direta da posição investigativa que o quarto dever prevê. Além de analisar criticamente informações que dizem respeito à companhia, o administrador deve também vigiar constantemente a atividade interna e fatores externos que podem afetar o desenvolvimento da companhia que administra (PARENTE, 2005, p.129). Aqui temos, novamente, espelhamento da evolução da figura de administrador pater famílias para administrador guardião ativo.

\subsection{3 - Dever de lealdade}

Assim como o dever de diligência, o dever de lealdade é uma importação do ordenamento norte-americano. É o denominado 'Duty of loyalty'. De acordo com o dicionário legal 'Wex' da 'Cornell Law School':

"O dever de lealdade se traduz no princípio de que diretores e administradores de uma companhia, ao tomarem todas as decisões em suas capacidades como agentes fiduciários da companhia, devem agir sem conflito econômico pessoal. O dever de 
lealdade pode ser violado ou através de uma transação de interesse pessoal ou através de um aproveitamento de oportunidade comercial" (tradução nossa).

No direito brasileiro, está previsto no artigo 155 da Lei nº.404/1976. Ao atentarmos para a redação do dispositivo legal e seus incisos e parágrafos, percebemos que a importação do termo é evidente.

Os três primeiros incisos são quase que uma reprodução da definição norte-americana. O parágrafo primeiro se traduz no dever de sigilo, que decorre diretamente do dever de lealdade. O parágrafo segundo traz apontamento interessante, na medida em que prevê que o administrador deve cuidar para que não haja quebra do dever de sigilo por parte de "seus subordinados ou terceiros de sua confiança".

Aqui vemos um desdobramento do dever de diligência que mencionamos anteriormente, especificamente do dever de vigiar. $\mathrm{O}$ administrador não deve apenas abster-se de quebrar o dever de sigilo, mas ter uma posição ativa no cuidado e observação para que essa quebra não seja feita por terceiro sobre o qual tem certo poder de vigiar.

O parágrafo quarto do artigo mencionado traz a figura do insider trading na esfera administrativa. Como mencionamos anteriormente, percebe-se que a previsão legal do insider trading administrativamente falando prevê como requisito o dolo de auferir vantagem indevida, diferentemente do tipo penal da Lei $\mathrm{n}^{\circ} 6.385 / 1976$.

Por fim, importante ressaltarmos que o dever de lealdade enseja no dever de informar, também advindo do direito norte-americano. De acordo com o dicionário legal 'Wex':

"Este dever requer que dirigentes ajam com 'completa franqueza'. Em algumas circunstâncias, isso exige que os dirigentes divulguem aos acionistas "todos os fatos e circunstâncias" relevantes para a decisão dos dirigentes" (tradução nossa). 
É a figura do processo de disclosure, que visa a abertura de informações e fatos relevantes ao público. Fica evidente aqui a influência do dever de informar no desenvolvimento do tipo penal de insider trading, posto que a violação dolosa do dever de informar tem, na maioria dos casos, o propósito de negociar valores mobiliários com informação privilegiada.

Cabe apontarmos, ainda, que o próprio dever de lealdade advém da relação de confiança que existe entre o administrador e a companhia, uma vez que a mesma só é devida por conta da relação fiduciária que existe entre as duas figuras.

\subsection{4 - Práticas não-equitativas}

A CVM define prática não-equitativa na alínea $d$ do inciso II de sua instrução n8/1979 como:

"no mercado de valores mobiliários, aquela de que resulte, direta ou indiretamente,
efetiva ou potencialmente, um tratamento para qualquer das partes, em negociações
com valores mobiliários, que a coloque em uma indevida posição de desequilíbrio
ou desigualdade em face dos demais participantes da operação".

Como podemos observar do transcrito acima, a definição é extremamente aberta e vaga. À primeira vista, percebemos que a definição é completamente inócua para o operador do direito. Essencialmente, a instrução abrange toda prática que não poderia ser considerada 'justa' ou 'devida' no âmbito das negociações com valores mobiliários. Além dos problemas filosóficos que surgem com a definição do que seria justo (como sempre acontece quando a equidade entra em discussão), a definição dada, por sua abrangência, não deveria ser uma estipulação feita em uma alínea de um inciso.

Entendemos que a lógica da proibição de práticas não-equitativas seria a de um princípio. É justamente por conta disso que a definição dada pela instrução da CVM é tão abrangente: não se trata de uma estipulação pontual, 
mas da explicitação de um princípio que deve reger as negociações com valores mobiliários.

O problema surge com o disposto no inciso III da referida instrução normativa, que prevê que "o descumprimento das disposições constantes desta Instrução" ensejarão a aplicação das sanções previstas no artigo 11, incisos I a VI da Lei nº.385/1976. No caso, a CVM trata a prática nãoequitativa como uma conduta que pode ser localizada pontualmente, posto que determina uma sanção para aquele que a realiza. Tal tratamento, apesar de não ser automaticamente excludente da noção de princípio, indica outra intenção do órgão regulador.

Neste ponto, fazemos nossas as críticas de Eizirik acerca da (falta de) aplicabilidade de uma norma sancionadora demasiadamente vaga:

"sem a precisa tipificação da conduta proibida, é impossível a aplicação de penalidades administrativas, uma vez que não se poderia exigir do acusado conduta diversa" (EIZIRIK apud CASTELLAR, 2008, pp.63-64).

Aplicando o conceito de prática não-equitativa da maneira que se encontra no nosso ordenamento jurídico, poderíamos sancionar quase qualquer atividade. Basta uma interpretação conveniente do termo 'indevida' para expandir a autoridade da CVM a quase qualquer caso.

Neste sentido, acreditamos que a lógica da vedação às práticas nãoequitativas deve ser empregada como uma diretriz principiológica. Apesar de se tratar de um conceito com aplicação eminentemente administrativa, é importante lembrar que a tipificação penal sofre indiretamente com definições vagas, posto que se apoia fortemente nos conceitos que se constroem a partir do âmbito administrativo do direito societário.

Faz-se oportuna a crítica de Castellar (2008, pp.62-63) acerca da importação da noção de práticas não-equitativas, no sentido de que 
estaríamos introduzindo, no nosso ordenamento jurídico, uma regra de equidade. Tal prática seria detrimental para nossa estrutura jurídica, que se assenta no direito continental, e não no sistema de common law regido por precedentes que, por conseguinte, está mais equipado para lidar com conceitos vagos. A inserção de uma noção baseada no princípio da equidade traria brechas para interpretações divergentes, sem que haja qualquer segurança jurídica. Este entendimento segue o raciocínio da crítica que fizemos anteriormente acerca da perigosa vagueza que a vedação às práticas não-equitativas apresenta.

Tendo em mente as mudanças trazidas pelo Código de Processo Civil de 2015, é possível que noções como equidade ganhem mais força no nosso ordenamento, em virtude da crescente importância que se dá aos precedentes. Dito isso, é cedo demais para entender que tal mudança salvaguardará a lógica da prática não-equitativa, que deve ser evitada ante nosso sistema de direito continental.

\section{6 - Considerações gerais sobre o crime de insider trading}

\subsection{1 - Consumação do crime de uso indevido de informação privilegiada}

A questão da consumação está, evidentemente, diretamente atrelada ao tipo objetivo do crime, que já discutimos anteriormente. No caso, trazemos as visões de respeitados doutrinadores para inserir nosso entendimento a seguir.

De acordo com Eizirik, o crime de insider trading é material. Como o doutrinador considera que o dolo específico de auferir vantagem ou causar prejuízo é necessário para que haja concretização do delito, e que obtenção da vantagem indevida é o resultado naturalístico que estaria previsto pelo 
delito, então o autor considera que o momento da consumação é o momento no qual a vantagem indevida é auferida (2011, p.565). Neste sentido, Castellar acompanha esta lógica da consumação (2008, p.119).

De forma geral, doutrinadores que consideram ser o crime de natureza formal entendem que a tentativa não é possível no insider trading. A exceção importante que encontramos foi De Sanctis.

De Sanctis afirma que o tipo penal prevê a necessidade de efetiva negociação com valores mobiliários, que por si só não é mera conduta que se perfaz instantaneamente (SANCTIS apud CASTELLAR, pp.123-124).

Entendemos que, apesar de se tratar de crime formal, o delito de insider trading admite a tentativa em raríssimas ocasiões. O núcleo do tipo penal é o verbo 'utilizar', que deve ser lido sempre no sentido de utilização para negociar com valores mobiliários. O ato de negociar não é instantâneo, por mais que assim o pareça com a tecnologia de hoje em dia.

Sendo assim, é possível que a utilização para negociação seja interrompida por circunstâncias alheias à vontade do agente (artigo 14, inciso II do Código Penal), não se perfazendo a negociação em si, mas ficando evidente a tentativa de negociação com valores mobiliários com uso de informação privilegiada por parte do agente.

Como mencionamos anteriormente na discussão do tipo subjetivo do delito, é possível que a informação virtual enviada na tentativa de negociação não seja recebida pelos servidores em virtude de alguma pane ou bug. Se a situação é improvável ou não, esta não é a discussão em questão. Basta que o perfazimento da conduta típica seja interrompível no seu iter criminis para que seja possível a tentativa, quer seja improvável ou não. 
Dito isso, entendemos que as circunstâncias que ensejariam a modalidade tentada do crime de insider trading são, de fato, difíceis de serem observadas na prática. Contudo, vislumbramos a possibilidade, e seguimos o entendimento de De Sanctis quanto ao requisito da consumação do crime de insider trading.

\subsection{2 - A pena e sua adequação}

A pena prevista para o crime de insider trading é a de reclusão, de um a cinco anos, cumulada com "multa de até três vezes o montante da vantagem ilícita obtida em decorrência do crime".

Com isso, cabe elucidarmos uma questão. A pena cominada para o delito de insider trading parece apontar para uma necessidade de auferimento de vantagem indevida. Argumentamos anteriormente que, numa leitura literal do tipo penal, a obtenção da vantagem não era necessária para que se consumasse o delito. Neste sentido, entendemos que a pena, ao prever a multa com base na vantagem indevida, não está criando condição para a conduta, mas apenas prevendo uma sanção proporcional ao dano causado.

A pena restritiva de liberdade seria imposta em virtude do cometimento do crime em si, e a pena de multa teria como propósito impedir que o agente se beneficie do ilícito, inibindo conduta futura. Se a pena prevê uma multa maior que a vantagem indevida, entende-se que serve de medida de prevenção de perpetuação da conduta no mercado de capitais.

Neste sentido, se houver tentativa de uso indevido de informação privilegiada, entendemos que a pena de multa não seria aplicável, posto que, evidentemente, o montante da vantagem ilícita auferida é zero. O artigo 27F da Lei $n^{\circ} 6.385 / 1976$ corrobora tal entendimento acerca da pena de multa, posto que prevê que seja aplicada "em razão do dano provocado ou da 
vantagem ilícita auferida pelo agente”. Se o agente não causou dano patrimonial ou auferiu vantagem ilícita ou indevida, então não é possível a aplicação de pena de multa. 


\section{CAPÍTULO 3 - MATÉRIAS ACESSÓRIAS E CONSIDERAÇÕES FINAIS SOBRE O INSIDER TRADING}

\section{1 - Análise da prevenção geral e especial no crime de uso indevido de informação privilegiada}

A questão da prevenção geral no direito penal econômico é extremamente polêmica e controversa. Grande parte da doutrina vem criticando o tratamento simbólico que vem sendo dado aos delitos penais econômicos, que seriam utilizados como veículo para uma espécie de catarse da população, cansada de ver a criminalidade de alta classe passar impune.

Sobre o assunto, Thompson traz elucidante relato acerca da cifra negra da criminalidade, em especial a da alta classe. O autor explica que a esmagadora maioria dos crimes de colarinho branco sequer são denunciados, quanto menos passíveis de condenação na prática do judiciário (THOMPSON, 2007, p.56). Neste sentido, grande parte da doutrina entende que o tratamento simbólico que mencionamos acima é uma manifestação da indignação generalizada para com a impunidade que permeia os crimes de colarinho branco.

Por mais que tal reação seja compreensível, é importante analisarmos o quadro fático. Na prática, o que vemos é uma artimanhosa seletividade na punição deste tipo de crime e uma exacerbação na aplicação de um direito penal sedento por vingança (CASTELLAR, 2008, pp.48-49). Os abusos da alta casta da sociedade devem ser combatidos, e assim vem sendo por corajosos servidores públicos, membros do Ministério Público e do Judiciário, mas devemos sempre estar atentos às repercussões sistêmicas que seguem este tipo de transformação. 
Tendo em conta o cenário atual, entendemos que, apesar dos esforços prestigiados, a prevenção geral do crime de insider trading carece de justificativa prática. Até o final de 2016, havia literalmente uma condenação por insider trading (na seara penal). Neste sentido, percebemos que não se trata de uma ausência da conduta típica, mas de uma cifra negra absurdamente colossal. $\mathrm{O}$ agente que comete crime de insider trading, em geral e hoje em dia, não teme ser pego ou preso por conta da conduta ilícita.

Em relação à prevenção especial, devemos analisar ambos os seus aspectos. Quanto à ressocialização, fica evidente que o problema não é estrutural, posto que o crime costuma ser cometido por pessoas em condições mínimas de conforto. Não enxergamos um forte viés ressocializador no crime de insider trading, posto que os crimes contra o mercado de capitais são recentes e surgiram como uma resposta aos abusos da alta classe, e não como uma maneira de adequar condutas nocivas. É evidente que toda norma penal visa tal feito, mas no caso do direito penal econômico, percebemos que se trata de uma intenção secundária.

Como, então, a pena ressocializaria um agente que cometeu crime de insider trading? Qual seria a estrutura e o apoio que lhe faltam? Ao nosso ver, não há. Sendo necessário o dolo e sendo o agente, de forma padronizada para fins de análise generalizada, relativamente educado e afortunado financeiramente, este sabe que sua conduta não é correta.

Neste sentido, entendemos que apenas o outro aspecto da prevenção especial surtirá efeito na conduta futura do agente condenado por prática do crime de insider trading. Tendo em mente nossa posição acerca do agente comum que pratica o delito em questão, o elemento com mais probabilidade de impedir sua reincidência seria o incentivo para que ele não o faça. A dor de ser sancionado por conta da prática do crime deve ser maior do que o benefício obtido pelo mesmo. 
Sendo assim, entendemos ser inútil a tentativa de ressocializar o agente condenado por prática de insider trading (salvo exceções, que sempre existem), devendo o foco estar no equilíbrio custo-benefício que se apresenta para o agente que tem potencialidade para reincidir.

Quanto à prevenção geral, cabe apontarmos que a única maneira de torna-la efetiva é aumentando esforços para que a cifra negra da criminalidade de classe alta seja diminuída significativamente.

\section{2 - Tutela penal ou administrativa?}

Seguindo o tópico acima, entramos na inevitável discussão da adequação do regime adotado para a repressão à prática do insider trading. Existem sanções administrativas e penais para a prática do ilícito, e nos resta saber se esta é realmente necessária ou não.

Inicialmente, cabe apontarmos que o direito penal clássico vem sendo aplicado há décadas, e é extremamente diferente do direito penal econômico em sua essência. Toda a estrutura policial e jurídica referente à criminalidade se moldou conforme a repressão a crimes clássicos, violentos ou não, e tem um viés pouco adequável ao direito penal econômico.

Neste sentido, a tutela penal já parece inadequada de pronto. No mínimo, seria necessária uma reestruturação. Na prática, a qualificação do judiciário para lidar com delitos do direito penal econômico é insatisfatória. A complexidade destes crimes, em especial do insider trading, exige especial atenção. Não estamos alegando que a justiça não é capaz de lidar com os mesmos, e sim que ela carece de estrutura para fazê-lo de forma adequada nos dias de hoje. Com isso, entendemos que um órgão regulador 
especializado, como a CVM, tem condições de lidar com estas práticas com muito mais eficiência, posto que foi edificado para atuar no contexto.

Além disso, trazemos aqui contundente observação de Alonso, ao afirmar que é contraditória a tutela administrativa e penal se o bem jurídico tutelado for o mesmo, por motivos óbvios:

\begin{abstract}
"Nesse contexto assume especial relevância o estudo acerca do bem jurídico, referente material necessário da norma penal. Uma solução plausível para se verificar a pertinência da intervenção penal no Mercado de Capitais consiste na aferição do bem juridicamente tutelado pelo direito administrativo sancionador, e do bem jurídico protegido pela norma penal. Dessa forma, a tutela penal no Mercado de Capitais somente se justificará caso se identifique um bem jurídico diverso - ainda que relacionado - daquele tutelado pela norma reguladora administrativa, adequando-se à sua função subsidiária" (2009, p.59)
\end{abstract}

Se o bem jurídico tutelado pela repressão administrativa for, por exemplo, o patrimônio dos investidores, então admitir o mesmo bem jurídico tutelado pela repressão penal significaria admitir que a administrativa é inócua. Por que haveria intervenção penal para tutelar um bem jurídico protegido pela norma administrativa, senão porque esta não é suficiente? Se for o caso, deveria ser abolida a norma administrativa, posto que não faria sentido um sistema que admite a inefetividade de uma tutela, mas a mantém mesmo assim.

Levando em conta o cenário atual, teoricamente, não vemos sentido na repressão penal. Tanto por ser uma admissão da ineficácia da sanção administrativa (que não nos parece sê-la na prática, tendo em mente as circunstâncias e a impunidade que costuma permear o meio), quanto por não fazer sentido na sua pena. Com a maior franqueza possível, não vemos justificativa razoável para prender um agente condenado por prática de insider trading, na teoria. Discussões sobre abolicionismos à parte, qual seria o propósito da prisão neste caso? Não vemos o insider como um perigo à sociedade fora do âmbito do Mercado de Capitais, e tal exílio é facilmente executável e previsto em outras legislações, e não vemos benefício em sua 
prisão. Neste sentido, cabe ressaltarmos que, se a tutela penal for considerada adequada, seria mais eficaz a aplicação de sanções visando impedir a atuação do condenado no Mercado de Capitais do que sua prisão. Este tipo de previsão existe em outras legislações, como o disposto no artigo 181 da Lei $\mathrm{n}^{\circ} 11.101 / 2005$, que prevê que aquele condenado pela prática dos crimes previstos na referida lei não poderá exercer atividade empresarial, função de conselho de administração, entre outros, e de "gerir empresa por mandato ou gestão de negócio". Na seara administrativa, tal tipo de sanção também é possível, como vemos nos incisos III e IV do artigo 87 da Lei no 8.666/1993, que prevê a impossibilidade de contratar com o poder público pelo descumprimento de contrato com a Administração Pública. Para argumentar a necessidade da prisão, poderíamos alegar a prevenção geral, mas acreditamos que esta pode ser alcançada sem o seu uso.

A pena de multa, por outro lado, nos parece extremamente adequada. Assumindo que o sistema funcione relativamente bem e que sejam condenados os infratores (único caso em que a discussão da pena não é vazia), entendemos que não há incentivo ao insider trading se a punição traz prejuízo maior do que o benefício obtido com a realização da conduta. Neste sentido, entendemos que a multa em si seria suficiente, posto que o problema que encontramos hoje em dia não está na ineficiência da multa como coação, e sim na não aplicação da mesma de forma eficaz. Se o condenado pode ocultar a vantagem obtida e não ser cobrado devidamente pelo poder público posteriormente ao cumprimento da pena restritiva de liberdade, a multa em si se torna inócua. Somente com a efetiva cobrança da mesma é que a sanção ganhará peso.

O condenado por insider trading deverá ser compelido a pagar a multa a todo custo, lhe sendo resguardado apenas o necessário para o mínimo existencial até que a dívida seja paga. Sendo aplicada desta forma, a multa é coação suficiente tanto para reforçar a prevenção especial respectiva à 
reincidência quanto à prevenção geral aos olhos daqueles que observam o peso da condenação.

Ante o exposto, como a pena de multa não é exclusiva do direito penal, não entendemos que a tutela penal seja necessária para coibir e combater a prática de insider trading. Dito isso, cabe fazermos uma ressalva de suma importância: tudo que expomos acima se aplica na teoria. Na prática, estamos diante de uma situação peculiar.

Em virtude da seletividade do sistema penal, entendemos que é difícil arguir pela não aplicação da tutela penal para o crime de insider trading nos dias de hoje. Ao nosso ver, uma enorme parcela da população carcerária não deveria estar presa, e sim punida por outros métodos. Neste sentido, como justificar a tutela administrativa do insider trading se a prisão é o primeiro recurso para punir condutas consideradas como extremamente nocivas à sociedade? Na prática, haveria uma inconsistência no discurso criminológico. Seria, novamente, um trunfo da alta classe sobre os criminosos do direito penal clássico.

Entendemos que, na prática, não faz sentido algum arguirmos a não aplicação da tutela penal para crimes contra o mercado de capitais num sistema que a aplica brutalmente aos crimes clássicos, inclusive patrimoniais não violentos (comparáveis ao insider trading em sua essência, por exemplo). Sendo assim, nos encontramos encurralados: entendemos que a tutela administrativa é suficiente e adequada para reprimir a prática do insider trading (se aplicada efetivamente), mas não podemos justificar tal tratamento a um delito penal econômico enquanto se mantém a violência sistêmica aos crimes clássicos.

Feitas as considerações e ressalvas acima, continuamos entendendo que a repressão penal não faz sentido no que diz respeito à repressão ao 
insider trading, na teoria. $\mathrm{O}$ ideal seria uma tutela administrativa com base na impossibilidade (temporária ou não, dependendo da gravidade da conduta) de atuação no Mercado de Capitais, e multa proporcional ao dano causado, sendo possível a aplicação de multa como inibidor da conduta.

\section{3 - The market for lemons e o insider trading}

George Akerlof escreveu, em 1970, um artigo intitulado "O mercado para limões: incerteza de qualidade e o mecanismo de mercado" (tradução nossa). De forma extremamente resumida, a tese de Akerlof visa explicar que a assimetria de informações causa uma degradação na qualidade dos produtos disponibilizados em determinado mercado.

O exemplo que o economista utiliza é o de mercado de carros usados. Havendo assimetria de informações, consumidores não conseguem distinguir um carro em boas condições de um lemon (carro cujo defeito é descoberto apenas após a compra). Sendo assim, o consumidor aceita pagar um preço médio, e os vendedores de carros bons não têm incentivo para vender. Por conseguinte, o mercado tem mais lemons, posto que o preço médio ainda é maior do que o valor de fato de um lemon. Com o aumento de lemons no mercado, consumidores se dispõe a pagar cada vez menos como resposta à queda na qualidade dos produtos, e o ciclo continua.

A tese pode ser aplicada ao insider trading de forma extremamente interessante. Como a conduta implica em assimetria de informações, entendemos que o paralelo que pode ser traçado merece uma breve discussão.

De forma análoga, a perpetuação do insider trading criará investidores menos dispostos a adentrar o mercado de capitais, uma vez que eles não podem averiguar o valor de fato dos valores mobiliários que negociam. Quanto mais insider trading o mercado tiver, mais degradada fica a sua 
integridade, e menos investidores se sentirão seguros para investir. Colin Read resume a analogia de forma contundente:

"[...] embora o preço de mercado esteja certo ao longo do tempo, sabemos que insiders estão tirando proveito de lucros enquanto os valores mobiliários se movem em outra direção. A analogia de Akerlof no market for lemons resulta numa conclusão parecida com a da lei de Gresham em relação a moeda legal contra moeda falsa - o ruim afasta o bom. Ninguém quer investir numa moeda se essa pessoa acreditar que há uma chance razoável de a moeda ser falsa. No caso de insider trading, quanto maior o grau de insider trading houver em um valor mobiliário, maior o grau de incerteza que um investidor teria quanto ao seu valor de fato. Assim como com a moeda, o investidor prudente iria simplesmente deslocar seu portfolio para um instrumento mais confiável e transparente, mesmo se em média o valor mobiliário propenso a insider trading estiver com o preço certo ao longo do tempo" $(2009$, p.8).

Neste sentido, entendemos que o bem jurídico que apontamos fica em perfeita sintonia com a analogia da tese do Market for lemons. Se o que a prática reiterada do Mercado de Capitais causa é uma degradação do próprio mercado, então é perfeitamente congruente entender que o bem jurídico tutelado pela repressão penal é a integridade do Mercado de Capitais. Como mencionamos anteriormente, a confiança dos investidores no Mercado de Capitais, o patrimônio dos investidores e das sociedades emissoras, e a igualdade formal, são todos elementos tutelados pela repressão ao insider trading, mas não são, por si só e individualmente, o bem jurídico que se busca tutelar. No fim, o que a prática do insider trading realmente danifica (e o que se visa tutelar, por conseguinte) é a própria integridade do Mercado de Capitais. 


\section{CONCLUSÃO}

Ao longo deste trabalho, a característica que mais se fez presente no que diz respeito ao crime de insider trading foi a ausência de consenso acerca de seus elementos basilares. $\mathrm{O}$ bem jurídico tem aproximadamente cinco correntes, nenhuma se apresentando de fato como a majoritária. Não se discute propriamente a vítima primária do delito, e sequer temos consenso sobre a leitura do próprio tipo penal, ou se estamos diante de um crime material ou formal.

Percebemos neste crime um reflexo das problemáticas que circundam o direito penal econômico de forma geral. A alta complexidade do crime, aliada à importação massiva de seus elementos constitutivos, reflete uma dificuldade em legislar sobre delitos econômicos. Tentamos incorporar um modelo estrangeiro (o norte-americano) mais desenvolvido e adaptá-lo à nossa realidade, e essa precariedade legislativa se faz clara na dificuldade e nas críticas da doutrina ao tratar a questão.

Percebemos também que o contexto do crime é de suma importância. Não muitas vezes o direito penal precisa entender matéria tão técnica alheia a si mesmo para ser aplicado com efetividade mínima. É impossível discutirmos o crime de insider trading sem um conhecimento mínimo de direito societário, tendo em mente que muitos dos termos que abordamos aqui são indispensáveis para a correta compreensão e adequação típica da conduta.

No fim, ficou evidente que ainda há muito trabalho a ser feito. Sem uma definição eficiente da conduta típica, não será possível exercer uma repressão eficiente ao insider trading. Devemos desenvolver a questão tanto no âmbito da fiscalização e denúncia da conduta, quanto no afunilamento do que poderá ser considerado como conduta típica penal. O direito penal não 
admite conceitos vagos, e a ausência de consenso jurisprudencial e doutrinário acerca do crime de insider trading e seus elementos constitutivos gera uma insegurança jurídica que dificulta a legitimidade da atividade persecutória no âmbito dos delitos econômicos. 


\section{BIBLIOGRAFIA}

AKERLOF, George A.. The Market for 'Lemons': Quality Uncertainty and the Market Mechanism. The Quarterly Journal of Economics, vol. 84, no. 3, 1970, pp. 488-500.

ALONSO, Leonardo. Crimes contra o mercado de capitais. São Paulo. 2009. 163 p. Tese (Mestrado em Direito Penal) - Departamento de Direito Penal, Medicina Forense e Criminologia da Faculdade de Direito da Universidade de São Paulo.

CASTELLAR, João Carlos. Insider trading e os novos crimes corporativos: (uso indevido de informação privilegiada, manipulação de mercado $e$ exercício irregular de cargo, profissão, atividade ou função). Rio de Janeiro: Editora Lumen Juris, 2008. 141 p.

COMISSÃO DE VALORES MOBILIÁRIOS. Uso Indevido de Informação Privilegiada (Insider Trading). Rio de Janeiro: Comissão de Valores Mobiliários, 2016. 45p. (Cadernos CVM, 11). Disponível em: <http://www.portaldoinvestidor.gov.br/portaldoinvestidor/export/sites/porta ldoinvestidor/menu/atividades/CampanhaNaoAoInsiderTrading/CVMCaderno-11.pdf>. Acesso em: 01/06/2017.

CORNELL LAW SCHOOL. Fiduciary duty. Disponível em: < https://www.law.cornell.edu/wex/fiduciary_duty>. Acesso em: 01/06/2017.

CORNELL LAW SCHOOL. Duty of loyalty. Disponível em: < https://www.law.cornell.edu/wex/duty_of_loyalty>. Acesso em: 01/06/2017. 
CÔRREA, Giovanna Marchetti de Azeredo Lopes. A punibilidade do insider trading no direito brasileiro. Rio de Janeiro. 2016. 90 p. Tese (Bacharel em Direito) - Departamento de Direito da PUC-Rio.

CORREA, Robson. Insider trading e a legislação brasileira. Disponível em: <https://robsoncorrea.jusbrasil.com.br/artigos/168985336/insider-trading-ea-legislacao-brasileira>. Acesso em: 01/06/2017.

DOWNES, John.; GOODMAN, Jordan Elliot. Dicionário de termos financeiros e de investimento. São Paulo : Nobel, 1993. 650 p.

DUBEUX, Julio Ramalho; BUGALLO ALVAREZ, Alejandro. A comissão de valores mobiliários e os principais instrumentos regulatórios do mercado de capitais brasileiro. Rio de Janeiro. 2005. 96 p. Tese (Mestrado em Direito) - Departamento de Direito da PUC-Rio.

EIZIRIK, Nelson et al.. Mercado de Capitais Regime Jurídico. $3^{\mathrm{a}}$ ed.. São Paulo: Editora Renovar, 2011. p. 554-567.

HENDERSON, M. Todd. The changing demand for insider trading regulation. In: BAINBRIDGE, Stephen M. (Org.). Research handbook on insider trading. UK \& USA: Edward Elgar, 2013. p. 245-248.

HOHENSTEIN, Dr. Kurt A.. Fait to all people: the sec and the regulation of insider trading. Disponível em: <http://www.sechistorical.org/museum/galleries/it/index.php>. Acesso em: 01/06/2017.

JOST, Mariana Silveira Martins. Insider trading: uma análise crítica. Rio de Janeiro. 2008. 75 p. Tese (Bacharel em Direito) - Departamento de Direito da PUC-Rio. 
MONROY, Antonio J. Antón. El abuso de información privilegiada em el mercado de valores. Madrid: DIJUSA, 2006. 175 p.

MORAES, Melina. A figura do insider trading no Brasil. Disponível em: $<$ https://melinamps.jusbrasil.com.br/artigos/148391458/a-figura-do-insidertrading-no-brasil>. Acesso em: 01/06/2017.

OLIVEIRA, Natália Silva Teixeira Rodrigues de. INSIDER TRADING: UMA REALIDADE À LUZ DO DIREITO PENAL. Rev. Fac. Direito UFMG, Belo Horizonte, n. 60, p. 365-390, jan./jun. 2012.

OLIVIA, Marcio Zuba de. O insider trading no brasil: breves considerações. Disponível em: <http://www.migalhas.com.br/dePeso/16,MI112842,81042O+Insider+Trading+no+Brasil+breves+consideracoes>. Acesso em: 01/06/2017.

ORPHÃO, Renata Santiago. Direito e transparência na divulgação de informações: a regulamentação brasileira versus a americana (lei SarbanesOxley). São Paulo: Textonovo, 2003. 157 p.

PARENTE, Flávia. O dever de diligência dos administradores de sociedades anônimas. Rio de Janeiro: Renovar, 2005. 260 p.

READ, Colin. The Market for lemons. In: ALI, Paul U.; GREGORIOU, Greg N. (Org.). Insider trading, global development and analysis. Florida, USA: CRC Press, 2009. p. 8.

SEC v. Texas Gulf Sulphur Co., 401 F.2d 833, 849 (2d Cir. 1968). Íntegra do caso disponível em: <https://h2o.law.harvard.edu/cases/3888>. Acesso em: 01/06/2017. 
THOMPSON, Augusto. Quem são os criminosos?:O crime e o criminosos: entes políticos. $2^{\mathrm{a}}$ ed.. Rio de Janeiro: Editora Lumen Juris, 2007. 177 p.

VIVIAN, Wilson de Alcântara Buzachi. Estudo sobre aspectos jurídicos do insider trading. Disponível em: <https://jus.com.br/artigos/35603/estudosobre-aspectos-juridicos-do-insider-trading >. Acesso em: 01/06/2017.

WERNECK, Luisa Falcão dos Santos. Insider trading - evolução histórica e estudo comparativo entre os sistemas americano e brasileiro. Rio de Janeiro. 2012. 57 p. Tese (Bacharel em Direito) - Departamento de Direito da PUCRio.

WIEDMANN, Natasha Pereira. A criminalização do insider trading no Brasil, suas principais controvérsias e o caso "sadia perdigão". Brasília. 2012. 93 p. Tese (Bacharel em Direito) - Faculdade de Ciências Jurídicas e Socais da UniCEUB. 